\title{
Climate Change: Leveraging Legacy
}

\author{
Michael P. Vandenbergh* \& Kaitlin T. Raimi, Ph.D.**
}

This Article explores whether a private governance initiative can harness legacy concerns to address climate change. The socio-temporal trap is an important barrier to climate change mitigation: The costs of reducing carbon emissions will be incurred by this generation, but most of the benefits will accrue to future generations. Research suggests that social influencesincluding concerns about legacy-can induce individuals to overcome collective action problems, but individuals know that future generations will not have information about who acted today in ways meriting social sanctions or rewards. Insufficient information may undermine three aspects of legacydriven behavior: the concern about how one's actions today will be viewed by future generations, the concern about how these actions will affect the social status of progeny, and the alignment of these actions with moral beliefs regarding the treatment of future generations. Making legacy-related information public today may also influence social sanctions and rewards from contemporaries. The Article examines the nature of legacy concerns, their effects on behavior, and the feasibility of a private legacy registry designed to record individuals' responses to climate change in ways that will not only be disclosed today, but will also be easily accessible for many generations.

Copyright (C) 2015 Regents of the University of California.

* David Daniels Allen Distinguished Chair of Law, Vanderbilt University Law School, CoDirector, Energy, Environment and Land Use Program, and Director, Climate Change Research Network. For valuable comments on this project, the authors would like to thank Cass Sunstein, Tali Sharot and the participants at the Public Policy and the Brain Exploratory Seminar, Radcliffe Institute for Advanced Study, Harvard University, as well as the participants at a Vanderbilt University Law School faculty workshop. The authors also would like to thank Emma Doineau for her outstanding contributions to the early development of the project, and Leland Frost and Amanda Nguyen for excellent research. Funding was provided by the Vanderbilt Institute for Energy and Environment/Climate Change Research Network and the Vanderbilt University Law School.

** Post-Doctoral Fellow in Energy and Environment, Vanderbilt Institute for Energy and Environment/Climate Change Research Network. 


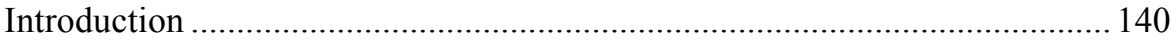

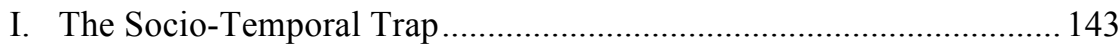

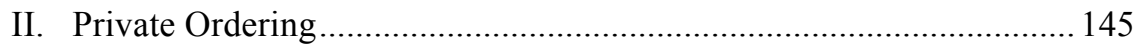

III. Norms, Legacy, and the Socio-Temporal Trap..................................... 148

A. Enforcement of Social Norms by Future Generations ................. 149

B. Effects of Social Norms on Offspring ……………...................... 151

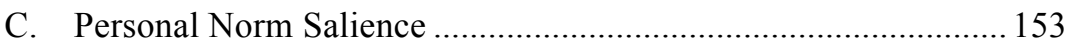

D. Enforcement of Social Norms by Contemporaries …………....... 155

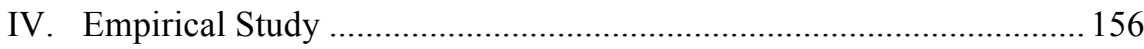

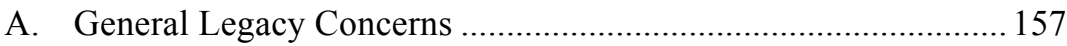

B. Anticipated Effects of Information Access on Reputation and

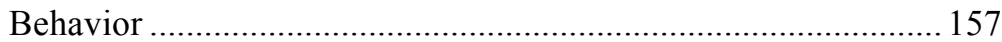

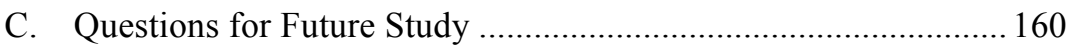

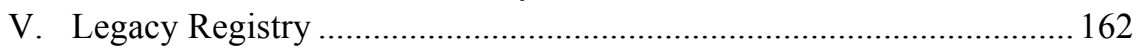

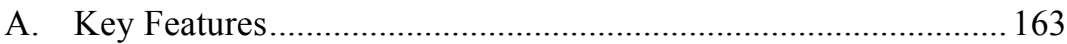

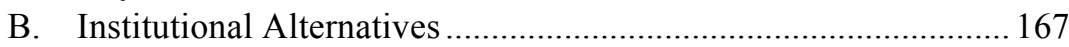

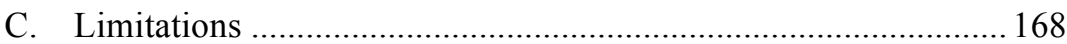

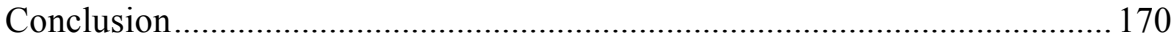

"And someday, our children, and our children's children, will look at us in the eye and they'll ask us, did we do all that we could when we had the chance to deal with this problem and leave them a cleaner, safer, more stable world? And I want to be able to say, yes, we did. Don't you want that?"

- President Barack Obama ${ }^{1}$

"The debt will soon eclipse our entire economy, and grow to catastrophic levels in the years ahead .... On this current path, when my three children-who are now 6, 7, and 8 years old - are raising their own children, the federal government will double in size, and so will the taxes they pay. The next generation will inherit a stagnant economy and a diminished country." - Congressman Paul Ryan ${ }^{2}$

\section{INTRODUCTION}

The rhetoric of legacy is common in law and policy, but legacy concerns are rarely harnessed in a systematic way to induce behavior change. This Article provides an example of how research on institutional design and on social and cognitive processes regarding legacy can generate new approaches to one of the most difficult problems - anthropogenic climate change. In 2007, the Intergovernmental Panel on Climate Change (IPCC) concluded that evidence of

1. Remarks by the President on Climate Change at Georgetown University (June 25, 2013), available at http://www.whitehouse.gov/the-press-office/2013/06/25/remarks-president-climate-change.

2. Joshua Norman, Paul Ryan: U.S. at "Tipping Point" over Debt, CBS News (Jan. 26, 2011, 2:19AM), http://www.cbsnews.com/news/paul-ryan-us-at-tipping-point-over-debt. 
anthropogenic climate change is unequivocal, ${ }^{3}$ and a survey of scientists who publish the most in the field found that roughly 97 percent agreed with the IPCC's core conclusions. ${ }^{4}$ Despite the increasing scientific evidence of anthropogenic climate change and extensive climate science dissemination efforts at the international, national, and subnational levels, public belief in climate science is declining, government policy makers have been unable to stem the growth of global carbon emissions, and the prospects for a comprehensive international treaty or national legislation in the United States are $\operatorname{dim} .{ }^{5}$

In the face of the difficulties confronted by governments at the international and national levels, policy analysts have begun to relax the assumption that the principal response should be a comprehensive international and national effort to price carbon and have begun to suggest other options, including bottom-up approaches, polycentric governance, regime complexes, climate clubs and climate accession agreements, and behavioral wedges. ${ }^{6}$ The new options offer the prospect of near-term emissions reductions that may buy time for more far-reaching or comprehensive national and international efforts. At the same time, efforts to develop gap-filling options are in the early stages and offer only a limited response thus far. In addition, although the new options reflect the dim prospects for an international or national carbon tax or cap-andtrade program, many of the new options rely on government legal or policy measures that are also subject to government gridlock.

Recent developments in private governance offer promising additional options. In the last several years, scholars in law, political science, economics,

3. See, e.g., Lisa Alexander et al., Summary for Policymakers, in IPCC, Climate CHANGE 2013: The PhysicAl SCIENCE BASIS 4 (Thomas F. Stocker et al. eds., 2013), available at http://www.ipcc.ch/report/ar5/wg1; LeNNY BeRnSTEIN ET AL., IPCC, Climate Change 2007: SYNTHESIS REPORT 72 (Rajendra K. Pachauri \& Andy Reisinger eds., 2007), available at http://www.ipcc.ch/publications_and_data/publications_ipcc_fourth_assessment_report_synthesis_repor t.htm; Jody Freeman \& Andrew Guzman, Climate Change and U.S. Interests, 109 COLUM. L. ReV. 1531, 1545 (2009); Richard J. Lazarus, Super Wicked Problems and Climate Change: Restraining the Present to Liberate the Future, 94 CORNELL L. REV. 1153, 1189 (2009).

4. See William R. L. Anderegg et al., Expert Credibility in Climate Change, 107 PROC. NAT'L ACAD. SCI. 12,107, 12,107 (2010).

5. See Elke U. Weber \& Paul C. Stern, Public Understanding of Climate Change in the United States, 66 AM. PSYCHOL. 315, 322 (2011).

6. See, e.g., David G. Victor, Global Warming Gridlock: Creating More Effective StRAtegies For PROtecting the Planet (2011) (citing climate accession agreements); Thomas Dietz et al., Household Actions Can Provide a Behavioral Wedge to Rapidly Reduce US Carbon Emissions, 106 PROC. NAT'L. ACAD. SCI. 18,452, 18,454-55 (2009) (providing examples of behavioral wedges); Robert O. Keohane \& David G. Victor, The Regime Complex for Climate Change, 9 PERSP. ON POL. 7, 9 (2011) (providing examples of regime complexes involving climate clubs); Elinor Ostrom, Nested Externalities and Polycentric Institutions: Must We Wait for Global Solutions to Climate Change before Taking Actions at Other Scales?, 49 ECON. THEORY 353, 365 (2012) (providing examples of polycentric governance regimes); Aseem Pakash \& Matt Potoski, Green Clubs: Collective Action and Voluntary Programs, 16 ANN. REV. POL. SCI. 399 (2013) (providing examples of green clubs); Richard Stewart et al., Building a More Effective Global Climate Regime through a Bottom-Up Approach, 14 THEORETICAL INQUiRIES L. 272, 287-88 (2013) (providing examples of bottom-up strategies for addressing climate change). 
and other fields have begun to explore how private institutions can bypass the national and international public policy gridlock on a wide range of issues. ${ }^{7}$ This emerging scholarship has begun to focus on environmental issues, ${ }^{8}$ and there is a growing recognition that new private institutional strategies may be able to achieve near-term carbon emissions reductions that bypass the government gridlock. ${ }^{9}$ This Article examines one of a suite of strategies in which the actors are private institutions and the actions are private governance - the pursuit of traditionally governmental ends and the performance of governmental functions by private institutions. ${ }^{10}$ The Article thus looks beyond public governance approaches to ask whether a prompt, private initiative focused on legacy concerns could motivate support for other private and public governance measures.

The Article begins with a short examination of how the social influences that might otherwise create pressure for individual and corporate carbon emissions reductions are undermined by the nature of the climate problem: future generations will bear the brunt of current emissions, but people living today likely assume that future generations will have little or no information about whether they acted today in ways meriting social sanctions or rewards. As a result, to the extent that social influences affect behavior, these influences are undermined by an intergenerational information problem. The Article reviews the social and cognitive literature on legacy concerns to examine the influence of legacy on individual, policy maker, and corporate behavior. Finding surprisingly little research on legacy issues, the Article presents preliminary data on values, beliefs, and norms associated with climate legacy.

7. See, e.g., Kenneth W. Abbott \& Duncan Snidal, The Governance Triangle: Regulatory Standards Institutions and the Shadow of the State, in THE Politics OF GLOBAL Regulation 44, 46 (Walter Mattli \& Ngaire Woods eds., 2009) (international relations); David P. Baron, Morally-Motivated Self-Regulation, 100 AM. ECON. REV. 1299 (2010) (economics); Tim Bartley, Certifying Forests and Factories: States, Social Movements, and the Rise of Private Regulation in the Apparel and Forest Products Fields, 31 POL. \& SoC'Y 433 (2003) (sociology); Steven Bernstein \& Benjamin Cashore, Can Non-State Global Governance Be Legitimate? An Analytical Framework, 1 REG. \& GOVERNANCE 347, 349-50 (2007) (political science); Michael P. Vandenbergh, The Private Life of Public Law, 105 Colum. L. ReV. 2029 (2005) (law); David Vogel, The Private Regulation of Global Corporate Conduct, 49 BuS. \& SoC'Y 68, 68 (2010) (management).

8. See, e.g., Michael P. Vandenbergh, Private Environmental Governance, 99 CORNELL L. REV. 129 (2013) (identifying emerging forms of private environmental governance).

9. For examples of private governance strategies to address climate change, see Kenneth W. Abbott, Strengthening the Transnational Regime Complex for Climate Change, 3 TRANSNAT'L ENVTL. L. 57 (2014) (examining international private governance responses to climate change); Eric W. Orts, Climate Contracts, 29 VA. ENVTL. L.J. 197, 198 (2011) (exploring public-private and private climate contracting); Stewart et al., supra note 6 (discussing private contracting as a bottom-up strategy); Michael P. Vandenbergh, Climate Change: The China Problem, 81 S. CAL. L. REV. 905, 939-40 (2008) (proposing supply chain contracting strategies to shift developing country climate incentives); Michael P. Vandenbergh et al., Energy and Climate Change: A Climate Prediction Market, 61 UCLA L. REV. 1962 (2014) (proposing a private climate prediction market to address climate science skepticism); Michael P. Vandenbergh et al., Time to Try Carbon Labelling, 1 NATURE Climate Change 4, 4-5 (2011) (proposing a global private carbon-labeling program).

10. See Vandenbergh, Private Environmental Governance, supra note 8, at 141-47 (defining private environmental governance). 
The Article then explores whether the intergenerational information gap could be addressed through a new private institution designed to ensure that individuals, policy makers, and firms in the current generation know that their responses to the climate threat today will be visible to future generations. Governments are not well situated to act in the near term to create this type of information collecting, preserving, and disseminating institution. A private legacy effort could enable politicians, private individuals, corporations, universities, and other institutions to self-disclose beliefs, actions, and policy positions, and could verify responses using data drawn from publicly available sources. A private registry could also store the information in ways that ensure long-term survival and easy retrieval by future generations. Care will need to be taken to address difficult logistical issues (e.g., long-term data storage and access), the influence of counterproductive norms, and biased self-reporting. The Article concludes by examining the prospects for this legacy project to influence individual and firm behavior, and it identifies research questions for legal scholars, social scientists, and policy makers.

\section{THE SOCIO-TEMPORAL TRAP}

Although many aspects of climate change make it a difficult problem, one of the most challenging is the temporal separation between the costs of emissions reductions and the benefits of reducing the harms caused by climate change. Climate mitigation approaches will require costly actions over the next several decades, but the near-term benefits during this period are modest. The most severe harms are not likely to begin until later this century, but they will continue for centuries afterwards. For example, even if atmospheric concentrations of greenhouse gases level off by 2020 , a scenario that is highly optimistic, the global average temperature will continue to increase for many decades, and sea levels will continue to increase for many centuries. ${ }^{11}$ As a result, many of the benefits of near-term emissions reductions will not arise for tens or hundreds of years.

The legal literature often examines climate governance challenges from an economic perspective, identifying carbon emissions as externalities and examining the collective action problems that undermine responses. ${ }^{12}$ Law and

11. David Archer et al., Atmospheric Lifetime of Fossil Fuel Carbon Dioxide, 37 ANN. REV. EARTH \& PLANETARY SCI. 117, 131 (2009) ("[T] he mean lifetime of fossil fuel [carbon dioxide] . . is 12-14 thousand years."); Susan Solomon et al., Irreversible Climate Change Due to Carbon Dioxide Emissions, 106 PROC. NAT'L ACAD. SCI. 1704, 1704 (2009) (“[T]he climate change that takes place due to increases in carbon dioxide concentration is largely irreversible for 1000 years after emissions stop."); see also DAvid M. ANDERson et AL., U.S. Global Change ReseArch Program, Global Climate ChANGE ImPACTS IN THE United STATES (Thomas R. Karl et al. eds., 2009), available at http://downloads.globalchange.gov/usimpacts/pdfs/climate-impacts-report.pdf (analyzing impacts of climate change "now and in the future"); NAT'L RESEARCH COUNCIL ET AL., AMERICA'S ClimATE CHOICES (2011) (discussing responses to climate change).

12. See Jonathan S. Masur \& Eric A. Posner, Climate Regulation and the Limits of Cost-Benefit Analysis, 99 CALIF. L. REV. 1557 (2011) (discussing use of cost-benefit analysis in climate regulation). 
economics scholars have noted that if individuals act in their self-interest, they will be reluctant to bear the costs of personal carbon emission reductions or of organizing to generate collective responses. ${ }^{13}$ Similar problems arise among nations. ${ }^{14}$ Climate change is an even trickier collective action problem than most because its solution not only requires collective action amongst individuals and nations, but also amongst this generation and future generations. Polls indicate that Americans have some understanding of this temporal gap: 40 percent of people think global warming will cause great or moderate harm to themselves and 45 percent think that members of their community will be affected, but as many as 63 percent think that it will harm future generations. ${ }^{15}$ Thus, the American people seem to recognize that the victims of climate change are different from the actors who contribute to carbon emissions today.

This time lag complicates and often obstructs efforts to mitigate climate change. In many fields, the concept of discounting plays a central role in thinking about current costs and future benefits. ${ }^{16}$ Research on individual decision making by lawyers, economists, psychologists, and neuroscientists suggests that even when collective action is not required, temporal discounting discourages individuals from making near-term sacrifices for their own personal future rewards, including environmental rewards. ${ }^{17}$

Psychologists offer a valuable additional perspective by distinguishing between social traps (collective action problems that arise between current individuals) and temporal traps (problems that arise between short- and long-

13. See, e.g., Eric A. Posner \& David Weisbach, Climate Change Justice (2010) (discussing this problem in the context of international climate change agreements).

14. See, e.g., VICTOR, supra note 6, at 30-58.

15. See anthony Leiserowitz et al., Yale Project on Climate Change Commc'N, George Mason Univ. Ctr. For Climate Change Commc'N, Climate Change in the American Mind: AMERICANS' GlobAL WARMING BELIEFS AND ATTITUDES IN APRIL 2013, at 9-11 (2013).

16. A line of research has debated the appropriate role that discount rates should play in climate policy decisions, which is beyond the scope of this Article. For a discussion of discounting and climate change, see William D. Nordhaus, A Question of Balance: Weighing the Options ON GLOBAL Warming Policies (2008); Kenneth Arrow et al., Determining Benefits and Costs for Future Generations, 341 SCIENCE 349, 349-50 (2013) (arguing for a double discount rate-a discount rate that decreases over time-with the decreasing discount rate reflecting uncertainty about future economic growth); Richard L. Revesz \& Matthew R. Shahabian, Climate Change and Future Generations, 84 S. CAL. L. REV. 1097 (2013); Thomas C. Schelling, Intergenerational Discounting, 23 ENERGY POL'Y 395 (1995); Sir Nicholas Stern, The Economics of Climate Change, 98 Am. ECON. REv. 1 (2008); David A. Weisbach \& Cass R. Sunstein, Climate Change and Discounting the Future: A Guide for the Perplexed (Harvard Law School Program on Risk Regulation, Research Paper No. 08-12, 2008), available at http://Articles.ssrn.com/sol3/Articles.cfm?abstract id=1223448.

17. See, e.g., Shane Frederick et al., Time Discounting and Time Preference: A Critical Review, 40 J. ECON. Lit. 351, 352-57 (2002); David J. Hardisty \& Elke Weber, Discounting Future Green: Money Versus the Environment, 138 J. EXPERIMENTAL PSYCHOL. 329, 338-39 (2009); Samuel M. McClure et al., Separate Neural Systems Value Immediate and Delayed Monetary Rewards, 306 SCIENCE 503, 503-04 (2004). The study conducted for this Article did not frame questions in terms of individual discounting, but the results are relevant to debates about individuals' differential valuation of current and future events, particularly social outcomes. 
run outcomes to an individual). ${ }^{18}$ If we think of the temporal trap as existing not just between current and future outcomes to an individual, but also between current and future outcomes for entire generations, the term "socio-temporal trap" captures the depth of the challenge faced by climate policy makers: They must convince members of this generation to sacrifice immediate gratification for later rewards not only for themselves, but also for other people, most of whom are not born yet. Carbon emissions reductions will require substantial costs in this generation, but climate effects lag behind carbon emissions by several decades and last for centuries. As a result, many of the most important benefits of carbon emissions reductions will not help the generation that sacrificed to mitigate climate change, but rather will avoid harm to later generations. ${ }^{19}$ Climate change mitigation can be thought of as a socio-temporal trap because members of this generation confront a problem that has both social and temporal aspects: They must pay costs that not only will benefit other people, but other people who do not yet exist. The response to climate change must thus involve not only individuals in one generation acting collectively, but also the current generation acting as if it had coordinated with future generations over the costs and benefits of action. This socio-temporal trap makes collective action to reduce emissions particularly difficult and places a premium on understanding the influences on behavior that will affect the distant future.

\section{PRIVATE ORDERING}

One answer to the socio-temporal trap is to create situations in which social influences can contribute to direct individual or corporate emissions reductions and to the development of climate laws and policies. An extensive literature on private ordering has developed over the last several decades, and the research has demonstrated that in some cases, social influences can address collective action problems, including problems involving natural resources and environmental concerns. ${ }^{20}$ This Part begins with an analysis of private ordering that draws from law and economics literature and then turns to contributions from social psychology and sociology. Both lines of thought have implications for the design of a private ordering response to the socio-temporal trap.

18. See generally David M. Messick \& Carol L. McClelland, Social Traps and Temporal Traps, 9 Personality \& Soc. Psychol. Bull. 105 (1983); John Platt, Social Traps, 28 AM. Psychol. 641 (1973). For a recent empirical study of the effects of intra- and intergenerational discounting on climate issues, see Jennifer Jacquet et al., Intra- and Intergenerational Discounting in the Climate Game, 3 NATURe Climate Change 1025 (2013).

19. See Solomon et al., supra note 11, at 1704-05.

20. See, e.g., Elinor Ostrom, Governing the Commons: The Evolution of Institutions FOR COLLECTIVE ACTION 90 (1990); ELINOR OSTROM, UNDERSTANDING INSTITUTIONAL DIVERSITY 259-60 (2005); see also Michael P. Vandenbergh, Beyond Elegance: A Testable Typology of Social Norms in Corporate Environmental Compliance, 22 STAN. ENVTL. L.J. 55 (2003) (reviewing empirical norms literature). 
Law and economics literature has examined the role of social norms at great length. ${ }^{21}$ For the purposes of this Article, social norms can be defined as informal obligations that are enforced externally through social sanctions or rewards. $^{22}$ In short, the literature on norms suggests that individuals have incentives to reduce social sanctions and increase social rewards just as they have incentives regarding pecuniary costs and benefits. ${ }^{23}$ Social norms can lead to social ordering in the absence of law, and can complement, undermine, displace, or encourage legal formation and enforcement. ${ }^{24}$

Research suggests that social norms can influence a wide range of behaviors, provided that adequate information is available to those enforcing the norms. ${ }^{25}$ In addition, in some situations iterative relationships or small groups may be necessary for effective norm enforcement. ${ }^{26}$ The challenge for development of private ordering responses to climate change is that the information and iterative relationship criteria are not met. Members of the current generation are likely to know that information will be hard to find. Not only will the current generation not be around to share in the benefits of its sacrifices today, but it will also not be the object of social sanctions or rewards. If social norm influences require these conditions, it will be difficult to harness social norms to address climate change.

The social psychology and sociology literatures use several related terms for the phenomena described here as norms (e.g., attitudes, values, descriptive norms, injunctive norms, and moral norms). Descriptive social norms are common patterns of behavior, whereas injunctive social norms are informal guides for how one should behave, and a large volume of research demonstrates that both influence behavior. ${ }^{27}$ Both descriptive and injunctive

21. See generally Robert C. Ellickson, Order Without Law: How Neighbors Settle DISPUTES (1991) (discussing social norms that influence order in the absence of law); ERIC A. POSNER, LaW And Social Norms (2002); Dan M. Kahan, Social Influence, Social Meaning, and Deterrence, 83 VA. L. REV. 349, 362 (1997); Richard H. McAdams, The Origin, Development, and Regulation of Norms, 96 Mich. L. REV. 338 (1997); Lior Jacob Strahilevitz, Pseudonymous Litigation, 77 U. CHI. L. REV. 1239, 1256 (2010).

22. See Michael P. Vandenbergh, Order Without Social Norms: How Personal Norm Activation Can Protect the Environment, 99 Nw. U. L. REV. 1101, 1105 (2005) (citing Stephen Hetcher, Creating Safe Social Norms in a Dangerous World, 73 S. CAL. L. REV. 1 (1999)) (discussing social norms and customs).

23. See, e.g., Kahan, supra note 21, at 378-79; Vandenbergh, Order Without Social Norms, supra note 22 , at 1104 .

24. See McAdams, supra note 21, at 347-50; Eric A. Posner, The Regulation of Groups: The Influence of Legal and Nonlegal Sanctions on Collective Action, 63 U. CHI. L. REV. 133, 137-45 (1996).

25. See Vandenbergh, Order Without Social Norms, supra note 22, at 1104.

26. See generally Hope M. Babcock, Assuming Personal Responsibility for Improving the Environment: Moving Toward a New Environmental Norm, 33 HARV. ENVTL. L. REV. 117, 140-41 (2009); Lior Jacob Strahilevitz, Social Norms from Close-Knit Groups to Loose-Knit Groups, 70 U. CHI. L. REV. 359 (2003).

27. See generally Robert B. Cialdini et al., A Focus Theory of Normative Conduct: Recycling the Concept of Norms to Reduce Littering in Public Places, 58 J. PERSONALITY \& Soc. PsYCHOL. 1015, 1015 (1990). See also Paul C. Stern et al., A Value-Belief-Norm Theory of Support for Social Movements: The Case of Environmentalism, 6 HuM. ECOLOGY REV. 81 (1999). 
norms are forms of social norms, those that contain information about other people. ${ }^{28}$ Psychologists and sociologists also find, however, that behavior is often guided by personal or moral norms.$^{29}$ For the purposes of this Article, personal norms are "obligations that are enforced through an internalized sense of duty to act and guilt or related emotions for failure to act." of personal norms has also been described by law and economic theorists, using such terms as personal norms, ${ }^{31}$ internalized norms, ${ }^{32}$ and identity. ${ }^{33}$ Empirical research has shown that many people share a set of abstract, personal norms. ${ }^{34}$ Although predictions about the influence of personal norms on behavior are difficult to make or test, empirical studies demonstrate that personal norms are widespread and affect behavior on a wide range of environmental topics. ${ }^{35}$ Recent research suggests that not only are individual behaviors influenced by personal norms, but decisions made by corporate managers regarding corporate environmental performance are influenced by personal norms as well. ${ }^{36}$

In theory, individuals living today could be induced to reduce their emissions and support emission reduction policies if they believed that social sanctions and rewards would occur, or if they were induced to do so by their personal norms. So far, however, normative influences have not been sufficiently strong to drive adoption of comprehensive national or international policy responses to climate change and have only led to limited individual actions and private governance. ${ }^{37}$ Are normative influences not sufficiently influential to yield substantial behavior change regarding carbon emissions, or does an effort to harness normative influences simply require a more sustained

28. See Cialdini et al., supra note 27.

29. See Stern et al., supra note 27 , at 85.

30. McAdams, supra note 21, at 376 (referring to internalization of norms); Vandenbergh, Order Without Social Norms, supra note 22, at 1105 (referring to "personal norms").

31. See Vandenbergh, Order Without Social Norms, supra note 22, at 1105.

32. See, e.g., Robert Cooter, Structural Adjudication and the New Law Merchant: A Model of Decentralized Law, 14 INT'L REV. L. \& ECON. 215, 218 (1994); McAdams, supra note 21, at 376.

33. See, e.g., George A. AKerlof \& RAChel E. Kranton, IdENTITY ECONOMics: How OuR IDENTITIES SHAPE OUR WORK, WAGES, AND WELL-BEING (2010).

34. See Shalom H. Schwartz, Are There Universal Aspects in the Structure and Contents of Human Values?, 50 J. SOC. ISSUES 19, 37, 46 (1994) (referring to common abstract personal norms as "value clusters"); Stern et al., supra note 27, at 85.

35. See, e.g., P. Wesley Schultz \& Lynnette Zelezny, Reframing Environmental Messages to Be Congruent with American Values, 10 HuM. ECOLOGY REV. 127 (2003) (discussing the role of personal norms - referred to as values - in support for pro-environmental policies and individual behaviors); Stern et al., supra note 27 , at 85 (citing studies of influences on environmentally significant behavior arising from values, beliefs, and norms).

36. See Robert Paternoster \& Sally S. Simpson, Sanction Threats and Appeals to Morality: Testing a Rational Choice Model of Corporate Crime, 30 LAW \& SoC'Y REV. 549, 583 (1993) (referring to "moral norms"); see also Sally S. Simpson et al., An Empirical Assessment of Corporate Environmental Crime Control Strategies, 103 J. CRIM. L. \& CRIMINOLOGY 231 (2013) (reporting the results of a survey on the norms of corporate managers).

37. See, e.g., Vandenbergh, Private Environmental Governance, supra note 8, at 147-61, 188-92 (citing studies of corporate behavior change associated with private environmental governance); Michael P. Vandenbergh \& Anne C. Steinemann, The Carbon-Neutral Individual, 82 N.Y.U. L. REV. 1673 (2007) (discussing studies of household behavior change). 
focus on overcoming the socio-temporal trap? The next Part examines the nature of legacy concerns in the context of norms and the role they may play in developing a response to climate change.

\section{NORMS, LEGACY, AND THE SOCIO-TEMPORAL TRAP}

Although iterative relationships cannot be created among distant generations, one response to the socio-temporal trap is to provide information that bridges the gap: to ensure that individuals living today are aware that individuals in future generations will know what they did in response to the threat of climate change. Did they acknowledge the importance of climate science or deny it? Did they reduce carbon emissions from their personal behavior or not? Did they support laws and policies that would reduce carbon emissions?

The answers to these questions, if widely available, could affect people's legacy concerns. ${ }^{38}$ Legacy beliefs have been defined as "individuals' convictions about whether they and their actions will be remembered, have an enduring influence, and leave something behind after death." 39 Scholars in the contexts of leadership, adult development, and self-esteem have found that when people are reminded of their own mortality, they react by trying to leave a positive personal legacy. ${ }^{40}$ Three aspects of legacy concerns could be affected by making people aware of the ways their climate-related behaviors align (or do not align) with social and personal norms.

First, the socio-temporal trap prevents future generations from enforcing social norms in one's lifetime, but knowing that one will be remembered well (or badly) could serve as a significant form of social norm enforcement. Second, social norms could be strengthened by the knowledge that one's offspring may bear the brunt of future social sanctions, even if the perpetrator of these norm violations is no longer around to receive them. Conversely, offspring may also receive benefits from their ancestors' laudable behaviors. Finally, the disclosure of climate-relevant information could make violations of personal altruism or environmental protection norms salient, thus invoking feelings of guilt and motivation to change behaviors even absent concerns about social norm enforcement. In addition, if climate-related actions were made public to contemporaries as well as future generations, then the classic

38. Other scholars have discussed the related issue of transferring wealth to future generations, another form of legacy. See, e.g., John Langbein, The Twentieth-Century Revolution in Family Wealth Transmission, 86 MICH. L. REV. 722 (1988) (discussing intergenerational wealth transfers). Although intergenerational wealth transfers are an important way in which people attempt to assist their offspring and maintain a positive posthumous reputation, they are beyond the scope of this Article.

39. Hannes Zacher et al., Age and Leadership: The Moderating Role of Legacy Beliefs, 22 LEADERSHIP Q. 43, 44 (2011).

40. See Kimberly A. Wade-Benzoni \& Leigh Plunkett Tost, The Egoism and Altruism of Intergenerational Behavior, 13 PERSONALITY \& SOC. PSYCHOL. REV. 165, 183 (2009); Zacher et al., supra note 39 , at 44 . 
method of inducing social sanctions and rewards may be able to stimulate climate change mitigation as well.

\section{A. Enforcement of Social Norms by Future Generations}

For other people to punish or reward norm-relevant behavior, they must first have access to information about whether individuals are conforming to or violating the norm. ${ }^{41}$ Yet the socio-temporal trap means that the people who are motivated to enforce norms are distant-temporally, physically, and psychologically—-from the individuals responsible for the negative outcomes. ${ }^{42}$ Barring time travel, future generations have no direct way to exact social sanctions for the current generation's bad climate behavior. They do still have an indirect means, however, to enforce social norms.

As Professor Cass Sunstein has noted, reputational incentives are an important component of social sanctions and benefits. ${ }^{43}$ A large body of research in social psychology has focused on how the desire to create and maintain a positive reputation can motivate a wide range of behaviors. ${ }^{44}$ People will even go so far as to risk their own health and safety in the pursuit of reputational gains. ${ }^{45}$ Furthermore, theorists have described how the desire for social acceptance can lead people to act in ways that bolster their social reputations even when other people are not physically present, because they can predict the potential social consequences of their immediate private behaviors. $^{46}$

Perhaps because of this desire for social acceptance, pro-social behaviors such as charitable giving can be inherently rewarding. Charitable giving is associated with activation of the mesolimbic reward system in the brain, as well as areas associated with social attachment. ${ }^{47}$ Public charitable giving, in which

41. See ELLICKSON, supra note 21, at 123-26 (discussing norm enforcement).

42. See Vandenbergh, Order Without Social Norms, supra note 22, at 1104-05 (discussing the limitations of social norm enforcement for environmental problems).

43. See Cass R. Sunstein, Social Norms and Social Roles, 96 Colum. L. REV. 903, 914-21 (1995).

44. See generally MARK R. LEARY, SELf-PRESENTATION: IMPRESSION MANAGEMENT AND INTERPERSONAL BEHAVIOR (1996) (explaining how self-presentation motivates behavior); BARRY R. SCHLENKER, IMPRESSION MANAGEMENT: THE SELF-CONCEPT, SOCIAL IDENTITY, AND INTERPERSONAL RELATIONS (1980).

45. See Mark R. Leary et al., Self-Presentation Can Be Hazardous to Your Health: Impression Management and Health Risk, 13 HEALTH PSYCHOL. 461, 461 (1994).

46. See generally Mark R. Leary, Sociometer Theory and the Pursuit of Relational Value: Getting to the Root of Self-Esteem, 16 EUR. REV. SOC. PSYCHOL. 75, 75 (2005) (referring to sociometer theory); McAdams, supra note 21 (referring to esteem theory).

47. See William T. Harbaugh et al., Neural Responses to Taxation and Voluntary Giving Reveal Motives for Charitable Donations, 316 SCIENCE 1622, 1622 (2007); Jorge Moll et al., Human FrontoMesolimbic Networks Guide Decisions About Charitable Donation, 103 PROC. NAT'L ACAD. SCI. 15,623, 15,623 (2006); Eva H. Telzer et al., Gaining While Giving: An fMRI Study of the Rewards of Family Assistance among White and Latino Youth, 5 SOC. NEUROSCIENCE 508, 508 (2010). 
people's social reputation can be bolstered by creating (or maintaining) a prosocial image, is particularly associated with reward processing. ${ }^{48}$

Most empirical research has focused on people's desire for good reputations during their lifetime, but less is known about the extent to which concern about posthumous reputation influences behavior. Hints of this desire can be found in research on mortality salience, which shows that reminding people of death leads them to seek social support and to make more pro-social decisions - the types of behaviors likely to improve their reputational standing after death. ${ }^{49}$ Further evidence for this link between social processes and mortality salience has emerged in neuroscience research, which has found that making mortality salient leads to activation in a brain region associated with the experience of love and attachment. ${ }^{50}$ Psychological research suggests that anxiety about death can be reduced through symbolic immortality, the ability to transcend death through the thought that one's family or community contributions will live on. ${ }^{51}$ In line with this idea, some preliminary neuroscience findings have also shown that making a bequest donation-as compared to a decision about pre-death charitable donations or volunteeringis associated with activity in visual areas of the brain that have traditionally been associated with third-person perspectives and autobiographical memories. ${ }^{52}$ Taken together, the psychology and neuroscience findings suggest that thinking about death involves visualizing how one is seen by oneself and by others.

More general support for legacy concerns can be found in the developmental psychology literature, which has shown that "generativity" concerns-concerns about creating and serving as a leader for future generations that are classically associated with middle adulthood-induce

48. Keise Izuma et al., Processing of Social and Monetary Rewards in the Human Striatum, 58 NEURON 284, 284 (2008).

49. See Matthew Fox et al., The Legacy Motive: A Catalyst for Sustainable Decision Making in Organizations, 20 Bus. ETHICS Q. 153, 158 (2009); Immo Fritsche et al., Existential Threat and Compliance with Pro-Environmental Norms, 30 J. ENVTL. PsYCHOL. 67, 68 (2010) (describing experiments tending to show a link between mortality salience and pro-environmental attitudes); Kimberly A. Wade-Benzoni et al., It's Only a Matter of Time: Death, Legacies, and Intergenerational Decisions, 23 PSYCHOL. SCI. 704, 704 (2012); see also Mark R. Leary et al., Distinguishing Intrapsychic from Interpersonal Motives in Psychological Theory and Research, 10 PERSP. ON PSYCHOL. SCI. (forthcoming 2015) (discussing behaviors motivated by a need to maintain self-esteem).

50. See Markus Quirin et al., Existential Neuroscience: A Functional Magnetic Resonance Imaging Investigation of Neural Responses to Reminders of One's Mortality, 7 SoC. COGNITIVE \& AFFECTIVE NEUROSCIENCE 193, 193 (2012) (identifying activity in the caudate nucleus).

51. See Gilad Hirschberger, Compassionate Callousness: A Terror Management Perspective on Prosocial Behavior, in Prosocial Motives, Emotions, AND Behaviors: The Better ANgels of Our NATURE 201-19 (Mario Mikulincer \& Philip R. Shaver eds., 2010).

52. See Russell N. James III, Assoc. Professor \& Dir. of Graduate Studies in Charitable Planning, Texas Tech Univ., Charitable Estate Planning as Visualized Autobiography: An fMRI Study of Neural Correlates, Presentation before the Erasmus Centre for Strategic Philanthropy, Erasmus University Rotterdam, Netherlands (Apr. 2, 2012), available at http:/www.erim.eur.nl/fileadmin/erim_content/ documents/James_Seminar_Neural_correlates_of_charitable_estate_pla.pdf (identifying the lingual gyrus and precuneus). 
people to act in ways designed to benefit future generations, including engaging in environmental activism. ${ }^{53}$ Reminding participants of their concerns about future generations can increase their personal engagement with environmental action. ${ }^{54}$ Similarly, political scientists have documented the work of presidents to establish legacies reaching beyond their terms of service and their physical lifetimes. ${ }^{55}$ Of course, presidents, unlike the average citizen, know that many of their acts and decisions will be recorded and made accessible to future historians, thus they are likely to be hyperaware of their posthumous reputation.

These lines of research suggest that if individuals living today believe that their immediate behaviors could affect their reputations many generations from now, they may act in ways favoring the preferences of those generations. This suggests that an initiative that provides a mechanism to make an individual's norm-relevant behaviors accessible to future generations could invoke a desire for a positive posthumous reputation. To be sure, the reputational norm enforcement created by such a project would be indirect-individuals would not receive feedback about the way their legacies have actually been viewed by posterity. A registry system that stimulates public debate about the likely views of future generations regarding climate or in which people are reminded of those preferences, however, has the potential to enhance the effects of the registry by acting as a guide to the probable consequence of immediate behaviors on future reputations.

\section{B. Effects of Social Norms on Offspring}

Another potential role of legacy information is to influence concern about the effects of social norms on progeny. Whereas individuals in this generation will likely evade the direct enforcement of pro-climate social norms by future generations, their offspring may not. Biologists have discussed how the norm of reciprocity can be translated into the treatment of offspring of deceased individuals, as in the case of a person who dies while performing an altruistic act and whose children receive the reciprocal benefits that would otherwise

53. See Bertrand Urien \& William Kilbourne, Generativity and Self-Enhancement Values in EcoFriendly Behavioral Intentions and Environmentally Responsible Consumption Behavior, 28 PSYCHOL. \& MARKeting 69, 82 (2011); see also ERIK H. ERIKSOn, ChILdHoOd AND SocieTY 267 (1950); M. Kyle Matsuba et al., Environmentalism as a Context for Expressing Identity and Generativity: Patterns among Activists and Uninvolved Youth and Midlife Adults, 80 J. PERSONALITY 1091, 1095 (2012); Lisa Zaval et al., How Will I Be Remembered? Conserving the Environment for the Sake of One's Legacy, PSYCHOL. SCI., Jan. 2015, at 1.

54. See Zaval et al., supra note 53, at 1 .

55. See John M. Murphy \& Mary E. Stuckey, Never Cared to Say Goodbye: Presidential Legacies and Vice Presidential Campaigns, 32 PRESIDENTIAL STUD. Q. 46, 46 (2002). 
have gone to their martyred parent. ${ }^{56}$ These benefits (and costs) of norm legacies also can take the form of reputational influences. ${ }^{57}$

Anecdotal examples suggest that reputation and social standing are often affected by the actions of ancestors. In some cases, descendants of prominent offenders will go to extreme lengths to avoid association with their inherited notoriety. ${ }^{58}$ Although the progeny of today's high-carbon emitters are unlikely to face the same reputational damage, they could still face stigma because of their ancestors' actions. Sociologists have noted that people often share in the stigma earned by their family members' more banal misdeeds or undesirable qualities ${ }^{59}$ so it is reasonable to assume that climate-harming behaviors could also earn intergenerational scorn.

In the same vein, the progeny of climate heroes could receive social benefits from their ancestors' actions. Just as the Sons and Daughters of the Revolution gain esteem and social benefits by their affiliation with patriotic forefathers, so could the children of those who change their behavior in response to the climate threat gain from their familial ties to climate mitigation. ${ }^{60}$ Many such positive legacy organizations already exist in the United States, including descendants of U.S. presidents, soldiers on both sides of the Civil War, passengers on the Mayflower, and early settlers of various cities and states, which suggests the importance that people assign to their ancestors' accomplishments. ${ }^{61}$ Similarly, research on the phenomenon known as "Basking in Reflected Glory" has demonstrated people's eagerness to connect themselves to the successes of others, and a registry documenting climate behaviors would be a direct avenue to do so. ${ }^{62}$

56. See Robert L. Trivers, The Evolution of Reciprocal Altruism, 46 Q. ReV. Biology 35, 35 (1971).

57. See Mojdeh Mohtashemi \& Lik Mui, Evolution of Indirect Reciprocity by Social Information: The Role of Trust and Reputation in Evolution of Altruism, 223 J. THEORETICAL BIOLOGY 523, 523 (2003).

58. See, e.g., HITLER'S CHILDREN (Maya Productions 2011). This is a documentary featuring stories of children of Nazi war criminals who have moved across the world, spent their lives writing about their parents' misdeeds, and even sterilized themselves to avoid passing on the genetic material of Nazis.

59. See generally ERving Goffman, Stigma: Notes on the Management of a Spoiled IdENTITY (1963) (referring to courtesy stigma); Michael Lewis, Shame and Stigma, in Shame: INTERPERSONAL BEHAVIOR, PSYCHOPATHOLOGY, AND CUltuRE 131 (Paul Gilbert \& Bernice Andrews eds., 1998) (referring to stigma contagion).

60. These offspring may also feel a need to "pay it forward" by creating a healthier climate for their own progeny. Research on reciprocity norms has shown that when people receive a benefit and cannot pay back their benefactor directly, they will often pass on that reciprocal benefit to third parties. See Sally Ann Shumaker \& James S. Jackson, The Aversive Effects of Nonreciprocal Benefits, 42 Soc. PSYCHOL. Q. 148, 148 (1979).

61. See, for example, the Mayflower Society; Sons/Daughters of Confederate Veterans; Sons/Daughters of Union Veterans of the Civil War; and the First Families of Georgia, South Carolina, Ohio, St. Louis, Twin Territories, New Haven, and Washington, among others.

62. See Robert B. Cialdini et al., Basking in Reflected Glory: Three (Football) Field Studies, $34 \mathrm{~J}$. PERSONALITY \& SOC. PSYCHOL. 366, 366 (1976). 
Thus, the promise (or threat) that a public record will exist of one's actions could remind people of the reputational inheritance they will leave their offspring. To the extent that future generations value climate mitigation, they may hold the children, grandchildren, and later generations of those who helped reduce climate change in higher social esteem than the progeny of those who simply added to the burden of climate change. An initiative to provide legacy information could serve both as a tool for future generations to gauge whose reputations should benefit (or suffer) due to the actions of their ancestors, and as a reminder to members of the current generation of the effects of their behavior on their offspring.

One limitation of this particular form of norm enforcement is that not all members of the current generation will have offspring. Those that do not may feel less responsibility for the reputational concerns of those who outlive them. Yet, they may still have personal connections to offspring of extended family members and nonfamily members of future generations, and they may desire for these individuals to benefit from that association. ${ }^{63}$

\section{Personal Norm Salience}

Even in the absence of social norms, some people may be motivated to protect the environment as a result of legacy concerns. Theorists have suggested that in some cases "[p]resent generations may choose a legacy of respect for the ecological rights of future generations without detailed familiarity or expectation of return,"64 but the influence of these types of personal norms on climate-related behavior is not well understood. Some law and economics theorists have conceptualized personal norms as social norms that have been internalized to such an extent that they are enforced not only by external social pressure, but by internal emotions such as guilt or pride. ${ }^{65}$ This allows the norms to motivate behavior even without social guides.

Although not a common focus of rational actor theorists, personal norms have been studied extensively in sociology and psychology. Personal norms can be held at varying levels of abstraction. ${ }^{66}$ For example, individuals may have an abstract personal norm to leave the world a better place for future generations, and this may or may not translate into a concrete personal norm to

63. See generally Lorraine M. Bettini \& M. Laurie Norton, The Pragmatics of Inter Generational Friendships, 4 COMM. REP. 64 (1991).

64. See Burns H. Weston, The Theoretical Foundations of Intergenerational Ecological Justice: An Overview, 34 HuM. RTS. Q. 251, 262 (2012).

65. See AKERlof \& KRANTON, supra note 33; GARY S. BeCKer, ACCOUNTING FOR TASTES 22530 (1996); Robert Cooter, Do Good Laws Make Good Citizens: An Economic Analysis of Internalized Norms, 86 VA. L. REV. 1577, 1595-96 (2000); Robert C. Ellickson, Bringing Culture and Human Frailty to Rational Actors: A Critique of Classical Law and Economics, 65 CHI.-KENT L. REV. 23, 4546 (1989); McAdams, supra note 21, at 376; Vandenbergh, Order Without Social Norms, supra note 22, at 1114 .

66. See McAdams, supra note 21, at 382; see also Cooter, supra note 32, at 1595-96; Vandenbergh, Order Without Social Norms, supra note 22, at 1114 (referring to first- and second-order norms). 
reduce their home electricity consumption. Empirical studies suggest that the abstraction of a norm affects its behavioral implications. When people focus on temporally or socially distant events, they do so in abstract and simplified ways. ${ }^{67}$ Conversely, current events are construed in concrete and complex ways. ${ }^{68}$ As to climate decisions, even those who hold abstract personal norms favoring climate change mitigation in the long term often fail to make the conceptual link to concrete personal norms about specific behaviors in the present, thus preventing adherence to their abstract pro-climate norms. ${ }^{69}$ Research suggests, however, that explicitly reminding people of the connection between concrete current behaviors and abstract personal norms can increase norm compliance. ${ }^{70}$

Indirect evidence for this need to remind people of their abstract personal norms can be seen in seemingly contradictory findings about age and climaterelated behaviors. Professors Kip Viscusi and Joni Hersch found that willingness to pay more for gasoline to address environmental issues decreases with age. ${ }^{71}$ This suggests that older adults may be less likely to act in climateprotecting ways - and from a self-interested view, this decision is perfectly rational, as older adults are the least likely generation to see personal benefits from climate change mitigation. What would happen, however, if people were reminded of their personal legacy-related norms? Research suggests that explicitly reminding people of their mortality can shift motivation from selfinterest to that of intergenerational beneficence - the idea being that giving to future generations is a way to connect to those generations and preserve a lasting legacy. ${ }^{72}$ The effect of mortality salience could lead to even more beneficence in older people than in the young, as mortality is more of an

67. See Pamela Smith \& Yaacov Trope, You Focus on the Forest When You're in Charge of the Trees: Power Priming and Abstract Information Processing, 90 J. PERSONALITY \& SOC. PSYCHOL. 578, 578 (2006); Yaacov Trope \& Nira Liberman, Temporal Construal, 110 PsYChOL. REV. 403, 403-21 (2003).

68. Trope \& Liberman, supra note 67, at 403.

69. See Kentaro Fujita et al., Think Globally, Act Locally: Construal Levels and Environmentally Relevant Decision Making, in Encouraging Sustainable Behavior: Psychology And THE ENVIRONMENT 81-100 (Hans van Trijp ed., 2013).

70. See Peter M. Gollwitzer \& Paschal Sheeran, Implementation Intentions and Goal Achievement: A Meta-Analysis of Effects and Processes, 38 ADVANCES EXPERIMENTAL SOC. PSYCHOL. 69, 69 (2006) (referring to goals rather than norms).

71. See W. Kip Viscusi \& Joni Hersch, The Generational Divide in Support for Climate Change Policies: European Evidence, 77 Climatic Change 121, 121 (2006).

72. See Wade-Benzoni et al., supra note 49, at 704. Psychology research makes mortality salient through a variety of methods, including having participants read about someone else's death, write about expectations of their own death, or walk in front of a funeral home. See, e.g., id. (reading); Chris Burgin et al., Breaking Apart the Typical Mortality Salience Manipulation: Two Questions, Two Outcomes, 21 EUR. J. SOC. PSYCHOL. 521, 532 (2012) (writing); Eva Jonas et al., The Scrooge Effect: Evidence That Mortality Salience Increases Prosocial Attitudes and Behavior, 28 PERSONALITY \& SOC. PSYCHOL. BULL. 1342, 1353 (2002) (walking). 
immediate issue for them. ${ }^{73}$ Thus, as Viscusi and Hersch note, characterizing climate change policies in a way that resonates with the concerns of older people may counteract the other factors that make them less willing to pay more for gas. ${ }^{74}$

Legacy information has the potential to bridge the gap between abstract and concrete personal norms by making abstract norms salient and by explicitly tying those norms to the concrete behaviors asked about in the process of providing data for the registry. Having a salient reminder of personal abstract norms also could prevent people from engaging in strategic ignorance- the tendency to ignore (or not seek out) information about the negative consequences of their actions. ${ }^{75}$ The act of providing information about one's climate-related behavior not only would make that information public to future generations, but it would bring the information to the individual's attention as well.

\section{Enforcement of Social Norms by Contemporaries}

Finally, although not strictly a legacy concern, social norms enforced by contemporaries are a powerful motivator of behavior. ${ }^{76}$ If legacy information were to make information about individuals' climate-relevant actions easily accessible to the current generation as well as future ones, then individuals could be subject to the social sanctions and rewards of their peers.

Depending on the exact specifications of a legacy registry, the registry also could have interesting effects on the development of new norms. Although most of the previous discussion has been about injunctive norms (informal rules for how one should behave), norms can also take the form of descriptive norms (guidelines about how most people actually behave). ${ }^{77}$ One potential criticism of a voluntary registry of climate-relevant behaviors is that only those who believe they are following the injunctive norm to mitigate climate change will participate. That asymmetrical participation could actually lead to more climate protection, however. To the extent that climate change believers may participate more than climate change doubters, contemporaries who view the registry will perceive a pro-climate descriptive norm indicating that much of the population is already acting to mitigate climate change. Researchers have shown that the perception of a descriptive norm, even an incorrect perception,

73. See Molly Maxfield et al., Age-Related Differences in Responses to Thoughts of One's Own Death: Mortality Salience and Judgments of Moral Transgressions, 22 PSYCHOL. \& AGING 341, 341 (2007).

74. See Viscusi \& Hersch, supra note 71, at 14.

75. See Jason Dana et al., Exploiting Moral Wiggle Room: Experiments Demonstrating an Illusory Preference for Fairness, 33 ECON. THEORY 67, 67 (2007); Fox et al., supra note 49, at 158.

76. See generally POSNER, supra note 21 (exploring social norms influencing behavior); McAdams, supra note 21 (same).

77. See supra note 27 and accompanying text. 
can lead people to conform to the perceived actions of others. ${ }^{78}$ Thus, contemporaries who perceive a norm favoring climate protection through a public registry may be motivated to act in climate-saving ways themselves.

\section{EMPIRICAL STUDY}

As noted earlier, little direct evidence exists about people's concerns for their posthumous reputations, despite a wealth of information about people's concerns for their reputation and social acceptance in their lifetimes. ${ }^{79}$ Although we have hypothesized that people will care about their reputational legacy, such a claim merits empirical verification. We set out to fill the gap in the legacy literature by measuring people's legacy concerns and the consequences of such concerns in the realm of climate change, and in this Part we present data and indications of the likely responses to key questions.

We conducted a brief study to test the extent to which people have reputational legacy concerns and whether such concerns motivate climaterelevant behaviors. Two hundred and five American adults (79 men and 126 women) were recruited through Amazon's Mechanical Turk (MTurk), an online survey tool. Participants ranged in age from eighteen to seventy-five, and 49 percent had achieved at least a bachelor's degree. Participants selfreported their responses to questions asking about their general and climatespecific legacy concerns, their predictions and desires for how they would be seen by future generations, and the likelihood that making climate information public to future generations would affect their environmental decisions. Information about demographics, political orientation, and climate beliefs was also measured to test whether climate-legacy concerns are stronger for certain people than for others.

The sample tended to believe strongly in climate change, although it included respondents from across the spectrum of climate change views. A composite was created from responses to four climate change questionswhether climate change is happening, whether it is caused by humans, how likely it is to threaten the participant's own health and safety, and how likely it is likely to threaten the health and safety of future generations-measured on 5point Likert scales that measured the participants' beliefs about the likelihood of climate change causes and outcomes, in which " 1 " indicated strongest climate beliefs and " 5 " indicated the weakest beliefs. ${ }^{80}$ Results showed that at least half of the respondents thought that climate change was at least probably,

78. See McAdams, supra note 21, at 366-67; Deborah A. Prentice \& Dale T. Miller, Pluralistic Ignorance and Alcohol Use on Campus: Some Consequences of Misperceiving the Social Norm, $64 \mathrm{~J}$. PERSONALITY \& SOC. PSYCHOL. 243, 243 (1993).

79. See supra note 44 and accompanying text.

80. For example, on the question of whether climate change was happening, " 1 " indicated that it was definitely happening, " 2 " indicated that it was probably happening, " 3 " indicated that it could be happening, and " 4 " and " 5 " indicated that it was probably or definitely not happening, respectively. 
if not definitely, happening. ${ }^{81}$ Responses were then divided into quartiles of climate belief for the analyses: very strong believers, strong believers, moderate believers, and doubters. ${ }^{82}$

\section{A. General Legacy Concerns}

To test whether people generally care about their posthumous reputation, people were asked to imagine that they had $\$ 100$ to buy a good reputation and that they could choose how to allocate that money between a good reputation in their lifetime and a good reputation after they died. The more money spent on each form of reputation, the better that particular type of reputation would be (but the worse the other form of reputation would be). As expected based on previous research showing the importance of reputation among peers, participants allocated more money to a good reputation in their lifetime (Mean $=62.49$, Standard Deviation $=24.34)$ than to a good posthumous reputation $($ Mean $=37.51$, Standard Deviation $=24.35) .{ }^{83}$ The fact that participants indicated a willingness to spend 38 percent of their resources on a posthumous reputation, however, indicates the importance of this previously understudied reputational concern.

\section{B. Anticipated Effects of Information Access on Reputation and Behavior}

For a registry to be successful in the enforcement of norms supporting climate change mitigation, participants must believe that the information will affect their reputation. The belief also should serve to motivate behavior change. To examine these issues, participants were asked two questions. For each question, participants were asked to consider six groups of people: people they know who are living today, strangers living today, their children, their grandchildren, future generations of their family whom they will never meet, and unrelated future generations. They were first asked to indicate how having climate-relevant actions known to each of those groups would change the groups' opinions of them. ${ }^{84}$ They then were asked to indicate how likely they would be to engage in more climate change mitigation if their actions would be known to these groups. ${ }^{85}$ Responses to these questions were then analyzed in two 6 (Audience) $\times 4$ (Climate Belief) repeated measures analyses of variance (ANOVAs) in which audience was a within-subjects factor. ${ }^{86}$

81. Median score was 1.75 , in between the 1 (definitely happening) and 2 (probably happening) response options.

82. Very strong believers $($ mean $=1$, standard deviation $=0)$; strong believers $($ mean $=1.38$, standard deviation $=.02)$; moderate believers $($ mean $=2.12$, standard deviation $=.64)$; doubters $($ mean $=$ 3.33 , standard deviation $=.94)$.

83. $F$-value $(1,203)=53.66, p$-value $<.001$.

84. Reported on a Likert scale ranging from "1 - much more negatively" to "7 - much more positively."

85. Reported on a Likert scale ranging from "1 - very unlikely" to "7 - very likely."

86. Greenhouse-Geisser corrections were used to account for violations of sphericity assumptions. 
For the analysis of the effects of information access on reputation, two significant main effects emerged. As can be seen in Figure 1 below, participants thought the various audiences would react differently to climate information. ${ }^{87}$ Participants thought that their children would see them the most positively, followed by people they knew and grandchildren. They thought that strangers and unrelated future generations would view them worst. Generally, participants showed a positivity bias, thinking that people would tend to look favorably on their climate behaviors, as all audience estimates were above the neutral midpoint. This finding was not moderated by climate change beliefs. There was, however, a main effect of climate change beliefs: the more strongly participants believed in climate change, the better they thought they would be rated by others who knew about their climate-relevant actions. ${ }^{88}$ Thus, it seems that people who doubt climate change have some intuition that future

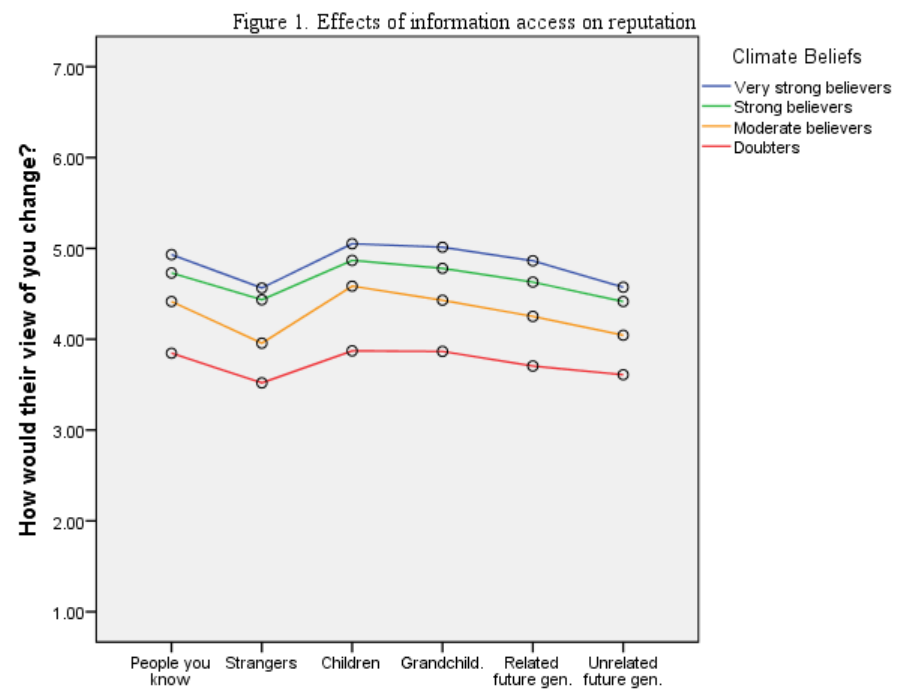

87. Main effect of audience: $F(2.92,586.52)=21.96, p<.001$. Pairwise comparisons showed that "people you know" did not statistically differ from "grandchildren" or "related future generations" and that "strangers" were not statistically different from "unrelated future generations." All other comparisons were significant (all $p s<.05$ ).

88. Main effect of climate change beliefs: $F(1,201)=13.99, p<.001$. Pairwise comparisons showed that the participants within the two strongest levels of climate change belief did not differ in their estimates of how information access would change their reputation $(p=.32)$, but that every step down from those levels of belief resulted in significantly more negative reputation predictions (all $p s$ $<.001)$. 


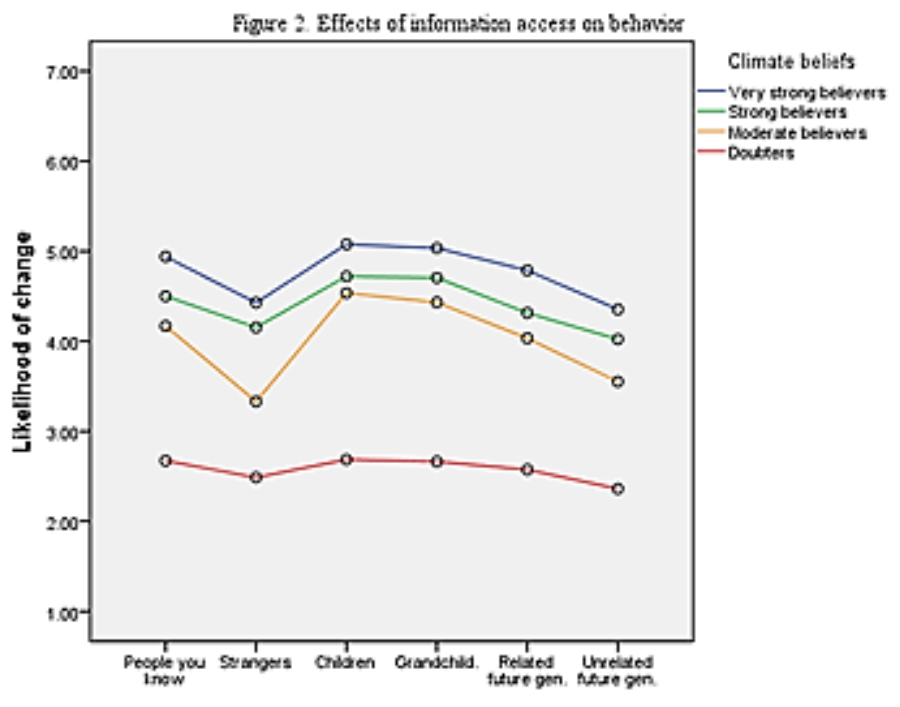

generations could hold their lack of urgency against them. In fact, climate doubters were the only ones who thought that access to information about their climate-related actions would damage, rather than boost, their reputation.

The optimistic views of the three groups of climate change believers may suggest another interesting finding. In short, believers in this generation may underestimate the likelihood that future generations will experience serious negative effects of climate change and will thus wish that the current generation had done more to stop it. The generally positive estimations that believers had about the effects of climate-related information sharing on their reputations may reflect an unwarranted positive illusion, rather than an accurate depiction of how they will be seen. The accuracy of current perceptions is discussed in more detail below, but the positive views of the participants may be consistent with psychological research showing that people often have overly positive perceptions of themselves and that they have trouble estimating how they are perceived when they lack clear information about contexts. ${ }^{89}$

Next, the effect of information access on behavior change was tested. Here, there was a significant interaction between participants' level of belief in climate change and the audience who they thought would learn about their behaviors (see Figure 2). ${ }^{90}$ Not surprisingly, climate change doubters reported that they would not engage in more climate change mitigation, no matter who had access to their climate change information. For all other participants, however, the audience did matter. People generally were most motivated to act

89. See generally Erika N. Carlson \& Michael R. Furr, Evidence of Differential Meta-Accuracy: People Understand the Different Impressions They Make, 20 PsYCHOL. SCI. 1033, 1033 (2009); Shelley E. Taylor \& Jonathan D. Brown, Illusion and Well-Being: A Social Psychological Perspective on Mental Health, 103 PSYCHOL. BULL. 193, 193 (1988).

90. Interaction effect: $F(8.67,580.66)=3.33, p<.001$. Simple main effects of audience emerged within every level of climate change beliefs other than the weakest level (all $p$ values $<.001$ ). Pairwise comparisons available upon request. 
by the possibility that their closest offspring (children and grandchildren) would have access to information, followed by people they knew and related future generations. Participants were relatively unmotivated by strangers and unrelated future generations. ${ }^{91}$ Yet, even knowledge that these relatively unimportant audiences would have access to information made strong climate change believers more likely than not to engage in behaviors to reduce climate change.

On the whole, these findings suggest that people not only care about their reputational legacy in general, but they also think that climate information could affect this reputation. Furthermore, participants who indicated at least a moderate belief in climate change said that the sharing of climate information would make them more likely to engage in climate change mitigation. Further research should test these legacy and reputational concerns on more representative samples, but these results suggest that people do care about the effect of climate information on their reputational legacy and are motivated to improve climate-related behaviors given the right legacy-sharing incentives.

\section{Questions for Future Study}

In addition to studying legacy concerns with more representative samples, a couple of further questions emerge from these findings. Most recent attempts to persuade the public about the dangers of climate change have focused on the near-term rather than the long-term risks of climate change. ${ }^{92}$ Although the risks for future generations are greater than for the current generation, advocates and policy makers appear to think that focusing on immediate risks will be more compelling for motivating the current generation to act. ${ }^{93}$ Not surprisingly, many climate policy and persuasion campaigns have focused on ways to alert the public to the immediate risks of climate change. ${ }^{94}$ Research does suggest that vivid personal experiences and near-term risks are much more motivating to people than abstract future possibilities. ${ }^{95}$ As Professor Elke Weber has noted, a visceral (negative) response to risk may be required to motivate change, and experience-based affective reactions to risk are more

91. This declining concern about future generations could reflect the type of personal discounting found by behavioral economists for temporally distant and uncertain outcomes. See, e.g., James Andreoni \& Charles Sprenger, Risk Preferences Are Not Time Preferences, 102 AM. ECON. REV. 3357, 3357 (2012).

92. For a discussion of this topic, see Elke U. Weber, Experience-Based and Description-Based Perceptions of Long-Term Risk: Why Global Warming Does Not Scare Us (Yet), 70 ClimATIC CHANGE 103 (2006).

93. See Andrew Revkin, Could Climate Campaigners' Focus on Current Events be Counterproductive?, N.Y. TIMES (Aug. 20, 2013, 10:14 AM), http://dotearth.blogs.nytimes.com/2013/08/20/could-climate-campaigners-focus-on-current-events-becounterproductive.

94. See Amy Luers et al., Climate Risks: Linking Narratives to Action, StAn. Soc. InNOvations REV. BLOG (Aug. 19, 2013), http://www.ssireview.org/blog/entry/climate_risks_linking_narratives_ to action.

95. See Weber, supra note 92, at 103. 
motivating than information-based cognitive reactions, even though these experience-based reactions often have little correlation with objective risk. ${ }^{96}$ The data from the present study suggest that near-term concerns are most important, but they also indicate that people do care about how their actions will be seen by future generations, especially those who are related to them. Future research could explore whether messaging that focuses on the relatively severe long-term implications of climate change could have important influences on behavior, especially if paired with reminders about legacy concerns. $^{97}$

Recent research has also suggested that people's perceptions of the length of their country's history affect their beliefs about the length of their country's future. ${ }^{98}$ Specifically, when people perceive long pasts, they also tend to predict longer lasting futures, and this belief in longer futures in turn leads them to have more concern about long-term environmental damage. Our legacy study was conducted with only American participants, but future research might test whether legacy messaging is particularly effective with citizens from older countries such as China, France, or England. In addition, framing the legacy registry we outline in Part V in a way that emphasizes the age of the country or culture might be a way to strengthen legacy concerns and further promote climate mitigation behaviors.

As discussed above, the legacy study data suggest that all but climate change doubters believe that making information public about the actions they are taking today will result in a boost to their posthumous reputation. This may be an accurate assessment of future beliefs and norms if shifts occur in the scientific understanding of climate change science, major new low-carbon technologies are developed and adopted globally, or geo-engineering becomes an inexpensive, feasible option. In the absence of one of these developments, future generations may look unkindly on individuals' current actions and policy support regarding climate change. Global emissions today are far above those necessary to achieve widely accepted atmospheric and temperature targets, and the large emissions by this generation will require substantial reductions by future generations. ${ }^{99}$ In addition, the delay in implementing climate mitigation

96 See id. at 103-20. In comparison, climate scientists have ample personal experience through their research on the impacts of climate change.

97. Including explicit information about severe outcomes could also help remove uncertainty about long-term risks, possibly the most important component in individuals' tendency to invoke hyperbolic discounting in temporal decisions. See supra note 91 and accompanying text.

98. See Hal E. Hershfield et al., National Differences in Environmental Concern and Performance Predicted by Country Age, 25 PSYCHOL. SCI. 152, 152 (2013).

99. For example, studies have suggested that, given existing emissions and atmospheric stocks, the average U.S. resident in 2050 will need to reduce emissions by 80 percent-from roughly twenty tons to roughly two tons - an amount equal to the per capita emissions of India today. See Vandenbergh \& Steinemann, supra note 37, at 1673. Several concrete examples suggest the difficulty of achieving emissions of two tons per capita: one international flight today from New York to London on average contributes roughly 0.65 tons of carbon dioxide emissions, and a year of driving a vehicle with the average current fuel economy contributes roughly 5.1 tons of carbon dioxide. OFFICE OF TRANSP. \& AIR QuAlity, EPA, GREenhouse GAS EMISSIONS FROM A TyPICAL PASSENGER Vehicle 2 
measures has been estimated to cost trillions of dollars, pushing large economic burdens onto future generations. ${ }^{100}$

It is possible that study participants believe that future generations will conclude that it was appropriate for this generation to oppose expensive mitigation measures even if the result is to increase the total cost by trillions of dollars. For example, participants may believe that future generations will view this generation's spending on infrastructure or consumption of consumer goods to have contributed to economic growth that improved the future generations' well-being more than the resulting carbon emissions harmed well-being, and thus to have been preferable to investments in climate mitigation. Participants also may believe that climate change will not be important relative to other issues that will affect their reputation. It is also possible that the participants simply lack information about the implications of delay or fail to understand that the harmful effects of climate change will continue for hundreds or thousands of years after atmospheric concentrations of carbon dioxide stabilize. ${ }^{101}$ Further research will be necessary to understand the reasoning behind participants' beliefs that future generations will view their current actions in a positive light.

\section{LEGACY REGISTRY}

The literature and empirical results discussed above suggest some prospect that if individuals know that future generations will have information about who acted today in ways meriting social sanctions or rewards, they will shift behavior. Information may affect the concern about how one's actions today will be viewed by future generations, the concern about how these actions will affect the social status of progeny, and whether these actions align with moral beliefs regarding the treatment of future generations. In addition, if legacy-

(2011), available at http://nepis.epa.gov/Exe/ZyPDF.cgi?Dockey=P100CZFN.PDF (year of driving); Total Carbon Emissions for Flight from London to New York, TRAVEL NAV, http://www.travelnav.com/flight-emissions/from/London,+United+Kingdom/to/New+York, +NY (last visited Feb. 4, 2015) (flight from London to New York). Although shifts away from fossil fuels by utilities and industries are likely to contribute a large share of the 80 percent reductions, it will likely be difficult to achieve 80 percent emissions reductions without individual behavior change as well.

100. See William D. Nordhaus, Why the Global Warming Skeptics Are Wrong, N.Y. REV. (Mar. 22, 2012), available at http://www.nybooks.com/articles/archives/2012/mar/22/why-global-warmingskeptics-are-wrong (suggesting that delaying climate mitigation by fifty years may increase total costs by $\$ 4.1$ trillion). The $\$ 4.1$ trillion figure may be a low estimate. See, e.g., Michael P. Vandenbergh \& Jonathan Gilligan, Macro-Risks: The Challenge for Rational Risk Regulation, 21 DUKE ENVTL. L. \& POL'Y F. 401, 412-19 (2011) (examining literature on the effects of mitigation timing on a range of potential climate outcomes).

101. See Robert T. Watson et al., Summary for Policymakers, in IPCC, Climate Change 2001: SYNTHESIS REPORT 5 (Robert T. Watson et al. eds., 2001), available at http://www.grida.no/climate/ipcc_tar/vol4/english/pdf/spm.pdf; see also John D. Sterman \& Linda Booth Sweeney, Understanding Public Complacency About Climate Change: Adults' Mental Models of Climate Change Violate Conservation of Matter, 80 ClimatiC CHANGE 213, 213 (2007) (demonstrating that even highly educated participants fail to apply basic principles of stock and flow to their mental models of climate change). 
related information is made publicly available today, it also may influence social sanctions and rewards from contemporaries. Major international and national government action may not be possible in the near term, but a private institution may be a viable option. ${ }^{102}$ This Part examines institutional designs that have the possibility of acting quickly and making a plausible claim that legacy-related information will be collected and made available not only today, but for centuries.

\section{A. Key Features}

To date, no sustained effort has been directed at gathering, maintaining, and disseminating information in a way that has the potential to harness legacy concerns. Legacy concerns have been identified as motivating factors by climate advocates, ${ }^{103}$ and legacy issues have been raised in a number of public pronouncements directed at motivating for climate policy action. For example, on the eve of the Copenhagen climate change negotiations, a group of global world leaders called "The Elders" emphasized the importance of acting now to prevent harms to future generations. ${ }^{104}$

Several elements are likely to be necessary to the design of an institution that can harness legacy concerns. Most important, the legacy project or registry should be designed to create an expectation in a large number of individuals that their actions and beliefs today will be known to future generations (we deal with the influences of nonlegacy information below). The registry could be structured under a voluntary model, in which participants self-disclose their beliefs, personal actions, and policy positions, ${ }^{105}$ or the registry organization

102. See Vandenbergh, Private Environmental Governance, supra note 8, at 197 (discussing domestic and global private governance options for climate change).

103. See, e.g., James Hansen, Storms of My Grandchildren: The Truth About the Coming Climate CATAStrophe and Our last Chance to SAve Humanity xii (2010) (sharing his motivation for becoming a climate advocate and scientist) ("I did not want my grandchildren, someday in the future, to look back and say, 'Opa understood what was happening, but he did not make it clear." ").

104. See Press Release, The Elders, The Elders Enlist Their Grandchildren's Help on Climate Change (Nov. 1, 2009), available at http://theelders.org/article/elders-enlist-their-grandchildrens-helpclimate-change. Among the ranks of The Elders were Kofi Annan, Nelson Mandela, Desmond Tutu, and Jimmy Carter. See What is The Elders?, THE ELDERS, http://theelders.org/about (last visited Jan. 3, 2015). In addition, President Obama discussed legacy issues in his 2013 inaugural address: "We will respond to the threat of climate change, knowing that the failure to do so would betray our children and future generations. Some may still deny the overwhelming judgment of science, but none can avoid the devastating impact of raging fires, and crippling drought, and more powerful storms." President Barack Obama, Inaugural Address (Jan. 21, 2013), available at http://www.whitehouse.gov/the-pressoffice/2013/01/21/inaugural-address-president-barack-obama. President Obama reiterated legacy issues in his July 2013 climate policy address: “[T]hose of us in positions of responsibility, we'll need to be less concerned with the judgment of special interests and well-connected donors, and more concerned with the judgment of posterity. Because you and your children, and your children's children, will have to live with the consequences of our decisions." Remarks by the President on Climate Change, supra note 1 .

105. Another format that could be followed is the "ethical will," a device through which individuals specify the wisdom they would like to impart to their heirs. See Howard Frumkin et al., 
could create a database drawn from publicly available sources (newspapers, public speeches, etc.). The registry also could include a hybrid of the two. A venue dedicated to preserving the names of adherents, such as a dedicated website, could offer a searchable record and facilitate access for future generations. Genealogical websites provide basic historical information but could be enhanced or serve as a model for a climate registry. Other sites, such as Wikipedia.org, also could act as searchable repositories or models for developing electronic storage venues for climate information.

The target audience could include the general public, corporations, nonprofit organizations, and policy makers. The design of the data collection and display may differ for each audience. To the extent the registry is a voluntary effort directed at individuals other than policy makers, to ensure an adequate number of participants, the information collection will need to be sufficiently quick and easy to overcome the "law of least effort"106 information submission that takes more than a short period is unlikely to attract more than a small, committed group of participants. If the registry were available to members of the current generation as well as to future generations, however, then participation might be heightened as people seek recognition and social rewards from their peers. This could be particularly powerful if the website or organization that collects this information includes a mechanism to acknowledge "successful" members. The individual, non-policy maker participant base need not include most of the population, although the prospects for shifting behavior and policy in meaningful ways are not great if the number of participants is too small. The data from the study suggest that individuals are more concerned about related than unrelated future generations, and this may suggest that the registry may be most attractive to participants if it functions like a reverse family genealogy site, emphasizing the ability of individuals in the current generation to convey information about climate beliefs and behaviors to their grandchildren, great grandchildren, and their offspring. One nonprofit, StoryCorps, has already achieved success with a similar model and has developed themed programs to record people's stories on specific social topics. ${ }^{107}$ Climate-related actions could potentially be the focus of a future

Aging, Climate Change, and Legacy Thinking, 102 AM. J. PuB. Health 1434, 1434-38 (2012). Making the will voluntarily encourages the creator to conform to it, for failure to honor one's word, when offered freely, carries a social stigma. If memorialized in a public forum, the desire to abide by the will may be reinforced.

106. For an overview of this concept, see DANIEL KAHNEMAN, THINKING FAST AND SLOW 31-38 (2012).

107. See StoryCorps Initiatives, STORYCORPS, storycorps.org/programs (last visited Jan. 3, 2015) (noting that current initiatives include military stories, stories from racial and ethnic minorities, and stories from people suffering from memory loss). Another indication of the potential influence of legacy concerns among consumers is the use of the concept by Seventh Generation, Inc., which "takes its name from the Great Law of the Haudenosaunee, which states that 'in our every deliberation we must consider the impact of our decisions on the next seven generations."' Profits with Purpose: Seventh Generation, FAST COMPANY (Dec. 1, 2007, 5:00 AM), http://www.fastcompany.com/social/2008/profiles/seventhgeneration.html. The slogan used by the firm is "We care today for the next seven generations of 
StoryCorps initiative, or this model could be adopted by other organizations. Given the success of firms that run genealogical research websites and other family history resources, it may be possible that the registry could be formed not as a nonprofit organization, but as a for-profit firm.

Verification of submissions by individuals may not be necessary-the process of submitting data, even if inaccurate for some, may have salutary effects. It may be possible to verify many aspects of submissions at low cost, though, such as through asking carefully drafted questions when the participant enters data into the registry. Other forms of verification are also possible, such as submission of verifying documents (e.g., utility bills), or links to any of a number of databases or internet-based programs that enable individuals to adopt and record progress toward low-carbon goals. ${ }^{108}$

Different concerns apply if the target participants are corporations or nonprofit organizations. For these organizations, ease of information submission remains important but probably takes a back seat to verification given the resources and sophistication these institutions can use to create the impression that they have taken favorable actions. For these organizations, a voluntary submission combined with a collection of public records (press accounts, lobbying positions and data, Securities and Exchange Commission filings, etc.) may be necessary. The same is true for policy makers, who have incentives to avoid hard choices today while arguing that they are forwardthinking.

One of the most difficult challenges is that the information will need to be stored in ways that ensure long-term survival and easy retrieval. This is necessary to ensure that participants today will have a well-founded belief that their information will be accessible to future generations. Electronic records have the advantage of being easily searchable if they can be accessed, but will they be readily accessible to individuals 50,100 , or 200 years from now? Ironically, commentators suggest that at this point data preservation may be best achieved by printing documents and preserving them on paper as long as possible. ${ }^{109}$ A recent survey of information technology administrators suggests that they have little confidence in data preservation over long periods of time. ${ }^{110}$ Threats to data preservation include human error, hardware obsolescence, software obsolescence, disaster, economic and component faults,

tomorrows." Who We Are, SEVENTH GENERATION, http://www.seventhgeneration.com/responsibility/ who-we-are (last visited Jan. 3, 2015).

108. See, e.g., CARBON SALON, https://www.carbonsalon.com (last visited Jan. 3, 2015) (providing a program to commit to carbon mitigation and linking with utility bills to provide data on behavior).

109. Michael Peterson et AL., 100 Year ARChive ReQuirements Survey 5 (2007), available at http://www.snia.org/sites/default/files2/100YrATF_Archive-Requirements-Survey_20070619.pdf; John Webster, How Long Is Long-Term Storage?, CNET (Aug. 13, 2009, 1:31 PM), http://news.cnet.com/8301-21546_3-10309283-10253464.html.

110. PETERSON ET AL., supra note 109, at 5-8. 
and lost metadata. ${ }^{111}$ In addition, any institution created to collect, preserve, and disclose data will need to wrestle not only with the physical issues related to the form of the data collection and storage, ${ }^{112}$ but also institutional issues to ensure that a viable entity will be able to facilitate access by future generations. Organizations in several research fields, national archives, and libraries are developing standards and technologies for the long-term preservation of digital data, ${ }^{113}$ however, and data storage experts have proposed several new methods for data preservation. ${ }^{114}$ At this point, the preservation of legacy data over several generations, or perhaps longer, appears to be a difficult but not insurmountable task.

The data collection and display could be limited to those who wish to announce their beliefs, carbon mitigation actions, and policy support. It also could be content neutral, enabling participants to indicate for future generations whether they supported or opposed climate change mitigation. Although there is some risk that a database that enables doubters to announce their views for future generations could undermine overall support for climate mitigation, the credibility of the registry may benefit from an open participant process. Indeed, vocal minorities in the climate change debate already have a disproportional presence in dispersed public forums such as comments on internet news sites. ${ }^{115}$ Creating a mechanism such as a legacy registry may help to counteract this effect by providing a forum for everyone to record their beliefs and behaviors, without having to engage in an online debate that could become vitriolic.

An electronic database is the most obvious structure but very different designs are also possible. For example, the information could be stored on a physical monument, allowing individuals who meet certain qualifications, such

111. See id; MARy BaKer \& Roger Cummings, Long-Term Preservation of Digital INFORMATION 8-11 (2010), available at http://www.snia.org/sites/default/files/MaryBakerRogerCummingsLong-term_Preservation_Digital\%20Information.pdf.

112. The challenges include media obsolescence, distributed or disjointed data organization, and file format obsolescence. See Ryan Layne et al., Long Term Preservation of Scientific Data: Lessons from JET and Other Domains, 87 FUSION ENGINEERING \& DESIGN 2209, 2209-10 (2012).

113. For example, the Library of Congress has authorized research of geospatial data preservation. See Greg JANÉE ET AL., A DATA Model AND ARChitecture FOR LONG-TERm Preservation 134 (2008), available at http://www.ngda.org/research/Tech\%20Arch/jcdl-paper.pdf.

114. For example, Professor Ethan Miller at the University of California, Santa Cruz, has proposed replacing widely used tape libraries with Pergamum, an approach that uses hard disk drives to provide energy-efficient, cost-effective storage. See Mark W. Storer et al., Pergamum: Energy-Efficient Archival Storage with Disk Instead of Tape, 33 USENIX MAG. 15, 15 (2008). The data preservation work coming from the aerospace and defense industries-largely funded by corporations like IBM, which must comply with regulatory requirements - may be another source of systems for long-term, easily searchable preservation of data. See, e.g., IBM, LONG-TERM DATA PRESERVATION SOLUTION (2012), available at http://public.dhe.ibm.com/common/ssi/ecm/ae/en/aes03013usen/AES03013USEN.PDF. In addition, the SanDisk Vault advertises the ability to hold photos for 100 years. See, e.g., SanDisk Memory Vault Technology, SANDISK, http://www.sandisk.com/go/preserve (last visited Jan. 3, 2015).

115. See NAOMI ORESKES \& ERIK M. CONWAY, Merchants of DOUBT: How a Handful of SCIENTISTS OBSCURED THE TRUTH ON ISSUES FROM TOBACCO SMOKE TO GLOBAL WARMING 169-215 (2011) (discussing the outsized influence of the vocal minority of climate deniers). 
as demonstration of low-carbon behaviors or policy support, to be listed for viewing by future generations. The Vietnam War Memorial, which has names engraved in marble or granite, and Mount Rushmore are rough analogues. Long-term preservation will require a physical memorial that is at a higher elevation than the Vietnam War Memorial, given projected sea level increases over the coming decades and centuries. ${ }^{116}$ The viability of this type of approach is suggested by the large number of examples of cause-driven physical memorials. For example, brick pathways, walls, and buildings inscribed with the names of institutional and individual donors are commonly found at universities. Gardens and public parks often have features such as stone markers, designated areas, or benches dedicated in honor of donors, founders, or contributors. A similar form of commemoration could be developed on a national scale or placed in local communities and personalized to regional tastes. Local manifestations of climate-related behavior may be more salient to individuals and more likely to affect progeny and the progeny of valued others, suggesting that some form of local effort may be important.

\section{B. Institutional Alternatives}

In theory, the legacy registry could be formed and managed by a private or public organization, enabling individuals to self-disclose their beliefs, personal actions, and policy positions, and including some degree of verification based on data from publicly available sources (newspapers, etc.), or it could be a public-private hybrid. Public and private organizations could compete to provide this service, and the private organizations could include for-profit firms and not-for-profit groups. Establishing a climate legacy registry may be a viable option for some states and local governments in the United States and by national and subnational governments in some other countries. The deep political divide over climate science and climate change mitigation measures at the national level in the United States and at the international level, however, suggests that activity at these levels is unlikely. As a result, a private governance response may be a more viable near-term option in the United States and in a number of other countries. ${ }^{17}$

116. See, e.g., Stefan Rahmstorf, A New View on Sea Level Rise, NAture ReP. Climate Change (Apr. 6, 2010), www.nature.com/climate/2010/1004/full/climate.2010.29.html (concluding that the most probable sea level increase by 2095 is 114 centimeters, with an upper bound of 200 centimeters).

117. For a discussion of the gap-filling role often played by private institutions, see Vandenbergh, Private Environmental Governance, supra note 8. 


\section{Limitations}

Regardless of its institutional form, a climate registry will confront several possible limitations. We explore several of the most important limitations below.

Logistics. The legacy registry discussed above is likely to rely heavily on the voluntary submission of private information and the collection of publicly available data. A climate registry may not attract widespread participation, but in the internet age many people have proved willing and eager to record their views on policy issues through the use of petitions, social media postings, and comments on online news articles. The ability of organizations to develop profiles on individuals (involuntarily and voluntarily) has been facilitated by this "reputation revolution." 118 The study results discussed above suggest some potential willingness to participate in a data collection effort, but a key to adequate participation may be to make recording data quick and easy. ${ }^{119}$ The technological challenges associated with long-term storage and retrieval of data may be the most important logistical hurdle.

Balancing Climate Mitigation and Other Contributions. The climate registry may be subject to the same concerns that confront climate mitigation expenditures generally: contributing to economic activity or nonclimate altruistic endeavors may help future generations, too. As a result, the overall implications of various behaviors for long-term social welfare may be unclear in some cases. It may be important to provide participants with information about the types of activities that are most likely to be beneficial, the rationale for focusing on climate mitigation, and an opportunity to record views and activities on other issues in the registry. For example, the registry could include information that would allow future generations to decide whether an individual's balance between climate and nonclimate actions and issues was worthy of social sanctions or rewards.

Unintended Consequences. As the discussion above suggests, the legacy registry could be structured as a neutral locus for participants to record information on their beliefs and behaviors, or it could include explicit information or reminders about pro-climate change mitigation norms. Even with explanatory measures, individuals with strong anti-climate change views may view a registry as a chance to voice those beliefs, and doing so might increase commitment to anti-climate science beliefs or anti-mitigation actions. This response could also lead to descriptive norm effects if doubters believe that their views are widespread. The study results suggest that only the most skeptical respondents are likely to have this view, however, and according to other research only about 7 percent of Americans believe with certainty that

118. See generally Lior Jacob Strahilevitz, Reputation Nation: Law in an Era of Ubiquitous Personal Information, 102 Nw. U. L. REV. 1667 (2008).

119. See Katrina Fischer Kuh, Personal Environmental Information: The Promise and Perils of the Emerging Capacity to Identify Individual Environmental Harms, 65 VAND. L. REV. 1565 (2012) (discussing private concerns associated with individual environmental behavioral initiatives). 
climate change is not happening, ${ }^{120}$ as compared to 40 percent of Americans who strongly believe that it is. ${ }^{121}$

For those who do not hold clear pro- or anti-climate change mitigation norms, it may be helpful to make climate science and mitigation information available during the registry process. Members of the current generation cannot be expected to know all of the relevant climate science or behavioral changes necessary to mitigate climate change, and the preliminary data suggest that knowledge of long-term climate effects and the extent of the optimal mitigation efforts may be quite limited. Climate mitigation might be encouraged through the registry by making such information explicit, but this approach could backfire if people see such explicit messaging as meddlesome.

In addition, for those who already hold pro-climate personal norms, participation in the registry raises the risk of moral licensing, thus inducing people to engage in more damaging subsequent behaviors. Research has demonstrated that people hold an internal balancing of moral acts, including environmental behaviors, and often follow good behaviors with bad. ${ }^{122}$ By making behaviors public and thus susceptible to social norm enforcement, however, pro-climate behaviors may be maintained, even in the absence of internal motivation to act in a pro-social manner. Making registry information public to the present generation should only increase such social pressure.

A related risk is that participants could lie to reap personal and social benefits. People have been known to respond to surveys in socially desirable ways by over-reporting good behaviors and under-reporting bad behaviors. ${ }^{123}$ This effect could be even stronger when people are recording responses publicly, rather than anonymously. ${ }^{124}$ Yet people are more likely to respond truthfully when they believe that their responses are verifiable by outside sources. ${ }^{125}$ Thus, the inclusion of some form of verification may be an important element of a registry. This verification will probably not prevent all socially desirable responses, but it will help to mitigate such a bias.

120. See LEISEROWITZ ET AL., supra note 15, at 5. Calculated based on the percentage of total survey respondents who indicated that they were very or extremely sure that global warming is not happening.

121. Id. at 3 .

122. See Nina Mazar \& Chen-Bo Zhong, Do Green Products Make Us Better People?, 21 PSyChOL. SCI. 494, 494 (2010); Sonya Sachdeva et al., Sinning Saints and Saintly Sinners: The Paradox of Moral Self-Regulation, 20 PSYCHOL. SCI. 523, 523 (2009).

123. See Anton J. Nederhof, Methods of Coping with Social Desirability Bias: A Review, 15 EuR. J. SOC. PSYCHOL. 263, 264 (1985).

124. See Philip M. Podsakoff et al., Common Method Biases in Behavioral Research: A Critical Review of the Literature and Recommended Remedies, 88 J. APPLIED PSYCHOL. 879, 888 (2003) (describing anonymity as a way to avoid socially desirable biases in self-reports).

125. See Neal J. Roese \& David W. Jamieson, Twenty Years of Bogus Pipeline Research: A Critical Review and Meta-Analysis, 115 PsyCHOL. BULL. 363, 363 (1991).

We welcome responses to this Article. If you are interested in submitting a response for our online companion journal, Ecology Law Currents, please contact ecologylawcurrents@boalt.org. Responses to articles may be viewed at our website, http://www.boalt.org/elq. 


\section{CONCLUSION}

This Article argues that a private climate legacy registry is a viable option that would make participants today aware that their beliefs, personal actions, and policy support will be known for many generations. If established by a private organization, the climate legacy registry could bypass the government gridlock that has prevented comprehensive national and international responses to climate change. The legacy registry could have an effect not only on the direct carbon-emitting behaviors of individuals, but also on the policy support of the general public, corporate leaders, and politicians. The data discussed in this Article suggest that many individuals care about their legacy and believe that future generations will judge their legacy in part based on their responses to climate change. A climate registry may increase the likelihood that individuals in the current generation will be willing to bear a share of the costs of carbon emission reductions today even though most of the benefits will accrue to future generations. Although not a climate mitigation panacea, a climate registry could be a viable way to harness legacy concerns. 